\title{
NOVEL DRUG DELIVERY SYSTEM THROUGH NASAL (NON-INVASIVE)
}

\author{
RAMACHANDRAN S, SHANMUGAPRIYA E, VIGNESHWARA KT, TAMILSELVAN M, SURSHA V
}

Department of Pharmaceutical Chemistry and Analysis, School of Pharmaceutical Sciences, Vels Institute of Science, Technology and Advanced Studies, Chennai, Tamil Nadu, India. Email: ramachandrans.sps@velsuniv.ac.in

Received: 10 October 2018, Revised and Accepted: 11 Decmber 2018

ABSTRACT

Intranasal route is the best method for high absorption and direct delivery to the brain. The interests and importance, of this route, are that the systemic effects of drugs when administered through the nasal route, have expanded over recent decades and it used for therapeutic and recreational purposes. In comparison with the parenteral route of drug administration, intra-nasal administration of drugs offers an interesting alternative for achieving systemic therapeutic effects of drugs. The oral administration of the drug produces low drug bioavailability, and this can be minimized using this nasal route. Moreover, the advantage of this route is that it can bypass the first-pass metabolism. Therefore, it is important to understand the potential and limitations of various nasal drug delivery systems. The aim of this review article is to discuss the various pharmaceutical dosage forms that have the potential to be utilized for local or systemic drug administration. It is assumingly expected that this review will help to understand about this route and also to develop suitable intra-nasal formulations to achieve specific therapeutic objectives. The different types of nasal drug formulations that can be used are nasal drops, nasal sprays, nasal gels, nasal suspensions and emulsion, and nasal powders.

Keywords: Intranasal, First-pass metabolism, Mucoadhesion, Bioavailability.

(c) 2018 The Authors. Published by Innovare Academic Sciences Pvt Ltd. This is an open access article under the CC BY license (http://creativecommons. org/licenses/by/4. 0/) DOI: http://dx.doi.org/10.22159/ajpcr.2018.v11s4.31705

\section{INTRODUCTION}

Nasal cavity is one of the best methods for delivering the drug because it has faster and higher drug absorption. By this method, we can avoid first-pass metabolism and also drug absorption from the nasal site is higher permission when compared to the gastrointestinal tract (GIT). Many drugs are gastro liable, so we can overcome that problem by intranasal system. Nasal therapy is also ancient therapy, and we can call it as "NASAYA KARMA" [1]

Drawback of the system is mucociliary clearance due to mucociliary clearance bioavailability is reduced and main advantage is it is of self-medication. By animal model, many nasal drug deliveries have been tested. Nowadays, nasal delivery comprised systemic and local therapeutic effect and used to treat.

1. Hay fever

2. Allergic rhinitis

3. Anaphylactic shock.

For systemic actions, many researches are going on, and the available pharmaceutical dosage forms such as gel, solution, and liposomes and this is designed for quick response to the drug which administered through nasal, for example, oxymetazoline [2]. In our system highly lipid soluble drugs can be easily distribute well [3]. Intranasal administration of a drug has advantages; it directly acts to brain without entering into systemic circulation. By nasal delivery process, many drugs were discovered, and human nasal is regulated by tight junctions especially paracellular pathway. Paracellular plays important role for nasal mucosa drug administering way [4].

\section{TIGHT JUNCTIONAL FORMATIONS}

Tight junctions are formed by internal membranes various proteins, tricellin, occluding, lipo-lysis stimulated lipoprotein receptor, and junctional adhesion molecule and these tight junctions are worked under cytokines (IL, TNF) interleukins, tuber necrotizing factor by transduction pathways [4].

\section{ANATOMY AND PHYSIOLOGY OF NOSE}

By anatomically respiratory system is divided into two types:

1. Upper respiratory tract

$$
\text { a. Nose }
$$

b. Pharynx

c. Larynx.

2. Lower respiratory tract
a. Trachea
b. Tracheobranchial
c. Bronchioles.

Air primarily enters by the nose through external nares and secondarily into pharynx finally to posterior nares [5]. The total surface area of the nose is $160 \mathrm{~cm}^{2}$, and it has volume about $16-19 \mathrm{ml}$ [6]. Warm, humid air enters into nose which also provides filtration of the inspired air and the unwanted particles get adhesive by the mucoadhesive process. Physiologically nose has (1) vestibular, (2) turbinate, and (3) olfactory [7] (Figs. 1 and 2).

Vestibular part is starting point of nose which is anterior and very narrow stiff hair inside the nostrils which protect from the environmental particles and is capable of filtering size about $10 \mu \mathrm{m}$ as it has stratified squamous epithelium [8]

The turbinate is highly blood perfusion area comprises three regions superior, middle, and inferior (Fig. 1) and turbinate is lined by pseudostriated columnar epithelium, and it is made by mucussecreting ciliated and non-movable microvillus which is highly responsible for increasing surface area due to non-movable response. The drug absorption is moderate. Ciliates are covered with motile cilia, and they are responsible for mucus transport of a drug that binds with mucociliary area as they could be expelled out and thus limited absorption only could occur [9-11]. The turbinate part consists of the following parts (a) vestibule, (b) atrium, (c1) inferior turbinate, (c2) middle turbinate, (c3) posterior turbinate, (d) olfactory bulb, and (e) nasopharynx [12].

Moreover, finally olfactory region and it's important for transporting the drug to brain and cerebrospinal fluid it comprises $8 \%$ of the total surface area it is made by non-ciliated, pseudo striated columnar epithelium and a mucus layer is present which traps unwanted particle and mucus 


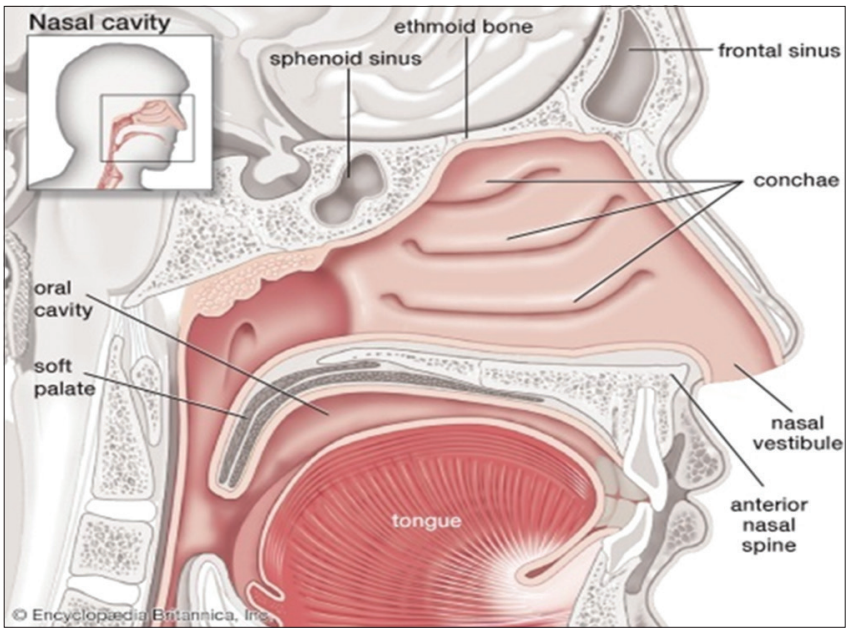

Fig. 1: Taken from Google

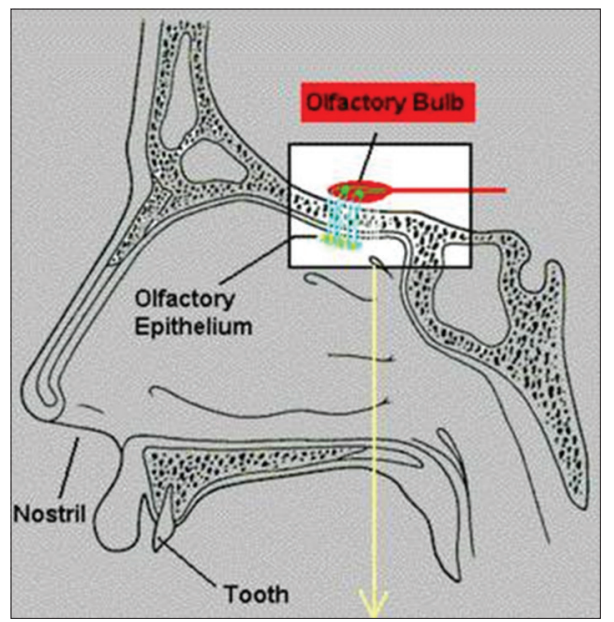

Fig. 2: Physiological diagram nose

secretion consists of salts, water, protein, albumin, immunoglobulins, and lysosomes [13]. pH of nasal secretions is about 5.9-6.5 [6,14].

Cells of nasal epithelium with covering mucus layer (a) ciliated cell, (b) non-ciliated cell, (c) corbel cell, (d) mucous gel layer, (e) sol layer, (f) basal layer, and (g) basement membrane [12].

\section{DRUG FORMULATION CONSIDERATIONS}

Nose has a higher surface area, which is potentially used drug delivery. The pharmaceutical development has a higher task for therapeutic objectives which is used for

- Local

- Systemic

- Single-repetitive dose loading

- By knowing the above status, it will be better for development of nasal delivery system is appropriate [15-17].

By knowing the factors that can affect drug absorption, disposition it can easy for making the novel, various pathological conditions and anatomical and physiological are also considered and in UK various nasal formations given in Table 1 [14].

\section{ENHANCEMENT OF DRUG}

Permission enhancer is added to the formulation which highly watersoluble [27]. The exact mechanism of absorption and permission is not known and the permission enhancer will induce the epithelial barrier modifications so that the drug entry becomes easy [26]. Above the given Table 2, different type of permission enhancer absorption is listed with the mechanism.

\section{NASAL DRUG DELIVERY ROUTE ADVANTAGES AND LIMITATIONS}

1. While comparing other routes such as parental, oral nasal has high potential, it directly delivers the drug to brain (through olfactory nerve), so the nasal route is much attractive when compared to other [30]. Brain is a delicate and highly perfused organ it has a lot of functions (sensory and collection processing and integrity finally motor actions). It is protected from the environmental factors, tight junctions surrounding the brain is called blood-brain barrier (BBB). It has a great transendothelial resistance which also blocks drug transport the delivery to brain by nose has many drug transport system such as (1) paracellular and (2) transcellular and/or neuronal pathway [31].

2. The presence of olfactory pathway it efficiently bypasses the BBB [32]. Nasal route is better alternative route for drug absorption and also in patient with problems such as GIT infections and GI route (or) parental route is inconvenient Example: Patient with Zollinger-Ellison syndrome, vomiting patient unable to swallow (achalasia), difficulties in children and old aged persons [33]. The important limitation of the nasal route is not applicable for all drugs. To increase the drug half-life, we must know about the physiochemical properties such as acid base disassociation constant (pk), partition coefficient, molecular weight, and drug solubility [34].

3. Many drugs formulations are solution type. They are very difficult to absorb due to polar and low solubility as these cause poor membrane permeability, instant clearance, and enzymatic degradation within nasal canal [6].

4. Drug or fillers which cause the local irritation to the nasal mucosa [35].

5. Formulation factors also have a great impact and type of formulation such as solid, liquid, gel, powder, and $\mathrm{pH}$ also included [36].

6. Physical conditions of the nose like nasal atrophic rhinitis which can reduce the nasal drug absorption and may also physiological condition such as blood flow, mucociliary clearance also plays an important role for reducing the nasal drug absorption $[33,37]$.

7. Presence of nasal mucous which also takes time for drug absorption and also reduces the contact time [38]. To overcome from the mucosa clearance by adding the mucoadhesive polymers in it (or) encapsulate with formulations so that bioavailability could be increased [39]. The drug absorption is distributed by major barriers is mucociliary and conditions like coryza, hay fever can change the mucociliary clearance, and some drugs may bind with mucins and decrease bioavailability of a drug [40-42].

\section{MECHANISM OF ACTION THROUGH NASAL ROUTE}

Mucous is the first step drug which has to pass through mucous layer tiny particles which may enter quickly and easily but larger particles have difficulties to enter [43]. Mucin is a protein substance present in mucous which has the potency to bind with drugs, and it alters the permeation process a structural modification of the mucus layer exists, so the result physiological changes occur [44]. The given drug that passes through mucous follows many mechanisms for drug absorption.

1. Paracellular

2. Transcellular

3. Transcytosis.

However, the paracellular and transcellular are major route [45].

\section{Paracellular}

It refers to the transfer of substances across an epithelium by passing through the intracellular spaces between the cells [46]. There is a direct correlation of a drug particle size and drug absorption because higher molecular weight does not cross well just bioavailability of the drug decreases [43]. 
Table 1: Current formulations of nasal drug delivery system [14]

\begin{tabular}{|c|c|c|}
\hline Indication & Active pharmaceutical ingredient & Formulation \\
\hline \multirow[t]{2}{*}{ Acute treatment of migraine } & 1. Sumatriptan & Nasal spray sol \\
\hline & 2. Zolmitriptan & Nasal spray sol \\
\hline \multirow[t]{2}{*}{ Analgesic } & 1. Fentanyl citrate & Powder and diluents for reconstituent aqueous \\
\hline & 2. Diamorphine HCL & spray nasal spray sol \\
\hline Endometriosis & Nafarelin acetate & Nasal spray sol \\
\hline \multirow[t]{4}{*}{ Nasal congestion, allergies } & 1. Xylometazoline HCL & Nasal spray, nasal drops \\
\hline & 2. Oxymetazoline HCL & Nasal spray, solution \\
\hline & 4. Ephedrine & Nasal drops \\
\hline & 5. Ipratropium bromide & Nasal sprays sol \\
\hline \multirow{5}{*}{$\begin{array}{l}\text { Prophylaxis and treatment of perennial and seasonal } \\
\text { allergic rhinitis }\end{array}$} & 1. Budesonide & Spray suspension \\
\hline & 2. Beclomethasone, dipropionate & Spray suspension \\
\hline & 3. Mometasone furoate & Spray suspension \\
\hline & 4. Fluticasone furoate & Spray suspension \\
\hline & 5. Fluticasone with azelastine HCL & Spray suspension \\
\hline \multirow[t]{2}{*}{ Prostatic carcinoma } & Buserelin acetate & Nasal spray \\
\hline & & Nasal solution \\
\hline Nasal congestion & Levomenthol & Nasal ointment \\
\hline \multirow[t]{2}{*}{ Nasal infection } & 1. Neomycin sulphate & Nasal cream \\
\hline & 2. Chlorhexidine dihydrochloride & Nasal cream \\
\hline Nicotine withdrawal symptoms & Nicotine & Nasal spray solution \\
\hline $\begin{array}{l}\text { Nocturia with multiple sclerosis, sensitive cranial } \\
\text { diabetes insipidus }\end{array}$ & Desmopressin acetate & Nasal spray solution \\
\hline Vaccination & Flu-vaccination & Nasal spray suspension \\
\hline
\end{tabular}

Table 2: Nasal drug absorption enhancers

\begin{tabular}{|c|c|c|c|}
\hline Class of compound & Example & Possible action & References \\
\hline Fatty acid & Lysophosphotidyl choline & Membrane disruption & [18] \\
\hline Surfactants & SLS, saponin, polyoxyethylene & Membrane disruption & [19-22] \\
\hline Bile salts & $\begin{array}{l}\text { Sodium glycolate, sodium deoxycholate, sodium } \\
\text { taurodihydrofusidate }\end{array}$ & $\begin{array}{l}\text { Enzyme inhibition, open tight junctions, } \\
\text { mucolytic activity }\end{array}$ & [23-25] \\
\hline Bio-adhesive material & Carbopol, starch microsphere, chitosan & Reduce nasal clearance, open tight junctions & [26] \\
\hline Enzyme inhibition & Amastatia & Enzyme inhibition & [27] \\
\hline Cyclodextrins derivatives & & Open tight junctions, membrane disruption & {$[28,29]$} \\
\hline
\end{tabular}

SLS: Sodium laryl sulfate

\section{Transcellular}

It is achieved with passive diffusion or transport mechanism [46]. Moreover, it also called lipoidal route it highly depends on lipophilicity of the drug, drug cross the membrane by active process using carrier [45].

\section{Transcytosis}

Drugs and macromolecules which are transported across the interior of the cell it forms a vesicle and transported to other side [46].

\section{NASAL DRUG DIFFERENT TYPES OF FORMULATIONS}

\section{Nasal drops and sprays}

Nasal drops by squeezing the bottle the nasal drops are used for local areas for local areas and also for mucociliary dysfunction [36,47]. Nasal delivery is easiest and simplest method for administration and also for formulations, and the major drawback of the system is contamination may occur during using periods and the exact and accurate amount of the drug administering also difficult [48]. The delivery is as follows:

\section{Nasal sprays contain a three parts \\ i. Chamber \\ ii. Piston \\ iii. Operating actuator.}

Advantages of nasal spray are more accurate than nasal drops measured dose can expel out [36]. Nasal spray shown a consistent dose of reproducible plume geometry the droplet size and dose accuracy can be depended on formulation properties such as surface tension, viscosity, and thixotropy [49-52]. The design of the pump and orifice size can affect the nasal disposition sprays $[17,48]$.

\section{Nasal gel}

By its characteristics, it is soft semisolid in nature and the semisolid characteristics can be two dynamic mechanical properties (i) elastic module G and (ii) viscous module G [34]. The flow properties of the nasal gel depends on vicious concentration and type of polymer for good results of biopharmaceutics bio-adhesive polymers plays a high role and these results a good improvement of patient complains $[53,54]$. A long time contact of a drug at the absorption site can increase the bioavailability because of slowing the mucociliary movement [55]. The mechanism of the mucoadhesive was explained by various theories, but the mechanism is generally based on two keys (i) contact and (ii) consolidation a long contact of polymer can diffuse with mucus [48]. Various non-harmful and biologically degradable polymers are discovered for mucoadhesive system ExamplePolyvinyl alcohol [56]. Mucoadhesive gels for nasal administration have been studied for different antibiotics such as ciprofloxacin [30], mometasone [57], carvedilol [58], and vaccines and proteins [59,60]. Some of the gels behave pseudoplasticity and their flow properties cannot be used for nasal delivery for this purpose gelation is used for overcome form that problem [61]. In polymeric formulations, the drug has to be solution form but after reaching into the body it should converted into gelation to the form of gel in a body depends on temp., $\mathrm{pH}$, and ions in a body [62]. 


\section{Nasal suspension and emulsion}

Nasal suspension formulations are rare nowadays and the relativity of marked aqueous eye drops is preparing example - sodium carboxymethylcellulose and loteprednol etabonate [63]. The preparation of nasal suspension of insulin was studied by Ando et al. 1998 [64]. The absorption enhancers were used for nasal suspension such as soybean steryl glycoside and sterol mixture and their pharmacological actions about $6.7 \%$ and $11.3 \%$ have been achieved [65-68]. For nasal formulations, emulsions are better chosen over suspensions because emulsions will enhance the rate and extend of a drug of poorly soluble drugs so that low solubility drugs have been encapsulated or formulated with emulsions for drug solubility example-diazepam [69]. Nasal-suspensions ranging from 1 to $500 \mathrm{~nm}$ for brain targeting and it crosses the BBB and researches going on nasal-emulsions [70-72].

\section{Nasal powders}

Nasal powder dosage forms are simply formulated by active pharmaceutical ingredients with fillers $[73,74]$. There are two types of drying spray drying and freeze drying [75-77]. The insulin is mixed with water-insoluble derivatives such as cellulose and Carbopol 934p and that was administered nasal way once the drug took by water it swells and gives the pharmacological action and glucose level got reduced by one-third using IV-insulin dose [78]. Bioadhesive polymers of nasal delivery were formulated by dry powders and nasal delivery of proteins and peptides it was first established by Nagai and Thogersen 1984 [79]. Beclomethasone dipropionate was coated with bioadhesive molecule and hydroxylpropyl used for carrier and it enhances the nasal resident time compared with nasal solution [80]. Indeed of highest bioavailability of the insulin was markedly decreased for the repeated administration of powder formulation [81]. The delivery drug has not been cleared from the nasal cavity because of physical barrier. Therefore it inhibits the drug penetration of inorganic substance such as calcium phosphate to enhance the drug absorption. This was demonstrated in rats for nasal absorption retardation at the site of administration which was proposed [74].

\section{CONCLUSION}

Nasal drug delivery system is one of the best potential and versatile routes for past many decades. It has a unique characteristic of drug release. It has bypassed the first-pass metabolism and also the drug has been directly delivered to brain so it has high potential of bioavailability. Various pharmaceutical dosage forms related to nasal utilized for the local or systemic drug has been discussed in this article intuitively, this review article will help for further new developed intranasal formulations to achieve the proper bioavailability practical and technical issue were discudded in this article a problem or difficulty to overcome for full potential to be realized.

\section{REFERENCES}

1. Alagusundaram M, Chengaiah B, Gnanaprakash K, Ramkanth S, Chetty MC, Dhachinamoorthi D. Nasal drug delivery system. Int J Pharm Sci 2010;1:454-65.

2. Ghoril MU, Mahdi MH, Smith AM, Barbara R. Conway nasal drug delivery system. Am Pharm Sci 2015;3:5

3. Satyanarayana U. Textbook of Biochemistry. Amsterdam: Elsevier Science; 2004. p. 9.

4. Himi T, Takano K editors. Excellence in Otolaryngology of Sapporo Medical University. Basel: Karger; 2016. p. 88-91.

5. Reddy LP. Fundamentals of Medical Physiology. $5^{\text {th }}$ ed. Oxford: Oxford University Press; 2013. p. 526.

6. Aulton ME, Taylor K. Aulton's Pharmaceutics and Design and Manufacture of Medicines. Edinburgh: Churchill, Living Stone; 2015.

7. Chien YW, Chang SF. International drug delivery system of systemic medications. Crit Rev Ther Drug Carrier Syst 1987;4:67-194.

8. Chien YW, SU KS, Chang SF. Anatomy and physiology of nose. In: Chen YW, SU KS, Chang SF, editors. Nasal Systemic Drug Delivery Drug and Pharmaceutical Science. Vol. 39. New York: Marcel Dekker; 1989. p. 1-19.

9. Singh L, Khan AD. Nasal drug delivery; a promising way for brain targeting. Pharm Res 2013;13:1-12.

10. Prajapati ST, Pathak SP, Thakkar JH, Patel CN. Nanoemulsion based internasal delivery of risperidone for nose to brain targeting. Bull Pharm Res 2015;5:6.

11. Mundlia J, Mukesh K. Nasal drug delivery, an overview. Int J Pharm Sci Res 2015;5:951-6.

12. UgWoke MI, Verbeke N, Kinget R. The biopharmaceutical aspects of nasal mucoadhesive drug delivery. J Pharm Pharmacol 2001;53:3-22.

13. Ozsoy Y, Tunçel T, Can A, Akev N, Birteksöz S, Gerçeker A, et al. In vivo studies on nasal preparations of ciprofloxacin hydrochloride. Pharmazie 2000;55:607-9.

14. Electronic Medicines Compendium. Database on Internet Datapharm Communications Ltd.; 2015. Available from: http://www.emc. medicines.org.uk.

15. Eller N, Kollenz CJ, Bauer P, Hitzenberger G. The duration of antidiuretic response of two desmopressin nasal sprays. Int $\mathrm{J}$ Clin Pharmacol Ther 1998;36:494-500.

16. Knoester PD, Jonker DM, Hoeven RT, Vermeij TA, Edelbroek PM, Brekelmans GJ, et al. Pharmacokinetics and pharmacodynamics of midazolam administred as concentrated intranasal spray. A study in health volunteers. Br J Clin Pharmacol 2000;53:501-7.

17. Vidgren MT, Kublik H. Nasal delivery systems and their effect on deposition and absorption. Adv Drug Deliv Rev 1998;29:157-77.

18. Merkus FW, Schipper NG, Hermens WA, Romeijns SG, Verholf JC. Absorption enhancers in nasal drug delivery; efficacy and safety. J Control Release 1993;24:201-8.

19. Natsume H, Iwata S, Miyamoto M, Kawai T, Sugibayashi K, Morimoto Y. Screening of absorption enhances for nasal peptide and protein delivery proceed internet symp. Control Release Bioact Mater 1996;23:481-2.

20. Zhou M, Donovan MD. Recovery of nasal mucosa following laureth-9 induced damage. Int J Pharm 1996;130:93-102.

21. Chandler SG, Illum L, Thomas NW. Nasal absorption in rats II effects of enhances on insulin absorption and nasal histology. Int J Pharm 1991;76:61-70.

22. Chandler SG, Illum L, Thomas NW. Nasal absorption in rats III lysophospholipids on insulin absorption and nasal histology. Pharm Res 1991;11:1623-30.

23. Aungst BJ, Rogers NJ, Sheffer E. Comparison of nasal, rectal, buccal sublingual and intramuscular insulin efficacy effects of bile salts absorption promotor. J Pharmacol Exp Ther 1998;224:23-7.

24. Yamamoto A, Morita T, Hashida M, Sezaki H. Effects of absorption promotors on nasal absorption of drug with various molecular weight. Int J Pharm 1993;93:91-9.

25. Bagger MA, Nielsen HW, Bechgaard E. Nasal bioavailability of peptide $\mathrm{T}$ in rabbits absorption enhancement by sodium glycolate and glycofural. Eur J Pharm Sci 2001;14:69-74.

26. Davis SS Illum L. Absorption enhancers for nasal drug delivery. Clin Pharmacokinet 2003;42:1107-28.

27. Touitou E, Barry BW, editors. Enhancement in Drug Delivery. Boca Raton: CRC press; 2006.

28. Marttin E, Verhoef JC, Merkus FW. Efficacy safety and mechanism of cyclodextrins as absorption enhancers in nasal drug delivery of peptide and protein drug. J Drug Target 1998;6:17-36

29. Matsubara K, Abe K, Irie T, Uekama K. Improvement of nasal bioavailability of LH Hormone releasing agonist, buserelin by cyclodextrin derivatives in rats. J Pharm Sci 1995;84:1295-300.

30. Ugwoke MI, Agu RU, Verbeke N, Kinget R. Nasal mucoadhesive drug delivery; background application trends and future perspectives. Adv Drug Deliv Rev 2005;57:1640-65.

31. Vyas TK, Shahiwala A, Marathe S, Misra A. Intranasal drug delivery for brain targeting. Curr Drug Deliv 2005;2:165-75.

32. Hanson LR, Frey WH $2^{\text {nd }}$. Intranasal delivery bypasses the blood-brain barrier to target therapeutic agents to the central nervous system and treat neurodegenerative disease. BMC Neurosci 2008;9 Suppl 3:S5.

33. Romeo VD, deMeireles J, Sileno AP, Pimplaskar HK, Behl CR. Effects of physicochemical properties and other factors on systemic nasal drug delivery. Adv Drug Deliv Rev 1998;29:89-116.

34. Chaturvedi M, Kumar M, Pathak K. A review on mucoadhesive polymer used in nasal drug delivery system. J Adv Pharm Technol Res 2011;2:215-22.

35. Harris AS. Review: Clinical opportunities provided by the nasal administration of peptides. J Drug Target 1993;1:101-16.

36. Hussein NR. Bio Adhesive Micro Particles and Liposomes of Anti Parkinson Drugs for Nasal Delivery. PhD Thesis University of Central Lanceshire; 2014.

37. Singh AK, Singh A, Madhv NV. Nasal cavity a pro messing trans 
mucosal. Platform for drug delivery and research approaches from nasal to brain. J Drug Deliv Ther 2012;2:22-33.

38. Jadhav K R, Gambhire MN, Shaikh IM, Kadam VJ, Pisal SS. Nasal drug delivery system-factors affecting and application. Curr Drug Ther 2007;2:27-38.

39. Suman JD. Nasal drug delivery. Expert Opin Biol Ther 2003;3:519-23.

40. Alagusundaram M, Chengaiah B, Gnanaprakash K, Ramkanth S, Chetty CM, Dhachinamoorthi D. Nasal drug delivery system an overview. Int J Res Pharm Sci 2015;1:454-65.

41. Sintov AC, Levy HV, Botner S. Systemic delivery of insulin via the nasal route using a new micro emulsion system; in vitro and in vivo studies. J Control Release 2001;148:168-76.

42. Upadhyay S, Parikh A, Joshi P, Upadhyay UM, Chotai NP. Intra nasal drug delivery system a glimpse to become maestro. J Appl Sci 2011;1:34-44.

43. Huang CH, Kimura R, Nassar RB, Hussain A. Mechanism of nasal absorption of drugs I: Physicochemical parameters influencing the rate of in situ nasal absorption of drugs in rats. J Pharm Sci 1985;74:608-11.

44. Shinichiro H, Takatsuka Y, Hiroyuki M. Mechanism for the enhancement of the nasal absorption of insulin by surfactants. Int $\mathrm{J}$ Pharm 1981;9:173-84.

45. Duvvuri S, Majumdar S, Mitra AK. Drug delivery to the retina: Challenges and opportunities. Expert Opin Biol Ther 2003;3:45-56.

46. Brahmankar DM. Textbook of Biopharmaceutics and Pharmacokinetic. New York: McGraw-Hill; 2018. p. 11.

47. Mahdi MH, Conway BR, Smith AM. Development of mucoadhesive sprayable gellan gum fluid gels. Int J Pharm 2015;488:12-9.

48. Washington N, Washington C, Wilson CG. Physiological Pharmaceutics Barrier to Drug Absorption. New York: Taylor and Francis; 2011.

49. Djupesland PG. Nasal drug delivery devices: Characteristics and performance in a clinical perspective-a review. Drug Deliv Transl Res 2013;3:42-62.

50. Hansen K, Kim G, Desai KG, Patel H, Olsen KF, Curtis-Fisk J, et al. Feasibility investigation of cellulose polymers for mucoadhesive nasal drug delivery applications. Mol Pharm 2015;12:2732-41.

51. Rassu G, Soddu E, Cossu M, Brundu A, Cerri G, Marchetti N, et al. Solid microparticles based on chitosan or methyl- $\beta$-cyclodextrin: A first formulative approach to increase the nose-to-brain transport of deferoxamine mesylate. J Control Release 2015;201:68-77.

52. Menaka M, Pandey VP. Formulation development and evaluation of cinnarizine nasal spray. Pharm Health Sci 2014;2:339-46.

53. Rathbone MJ, Hadgraft J, Roberts MS, editors. Modified Release Drug Delivery Technology. Boca Raton: CRC Press; 2002.

54. Nakumura K, Tanaka Y, Sakurai M. Dynamic mechanical properties of aqueous gellan solution sol-gel transition region. Carbohydr Polym 1996;30:101-8.

55. Patil SB, Sawant KK. Mucoadhesive microsphere; a promising tool in drug delivery. Curr Drug Deliv 2008;5:312-8.

56. Pasha M, Ngn S. Derivatization of guar to sodium carboxy methyl hydroxy propyl derivative; characterization and evaluation. Pak J Pharm Sci 2008;21:40-4.

57. Zitt M, Kosoglou T, Hubbell J. Mometasone furoate nasal spray: A review of safety and systemic effects. Drug Saf 2007;30:317-26.

58. Saindane NS, Pagar KP, Vavia PR. Nanosuspension based in situ gelling nasal spray of carvedilol: Development, in vitro and in vivo characterization. AAPS PharmSciTech 2013;14:189-99.

59. Vila A, Sánchez A, Tobío M, Calvo P, Alonso MJ. Design of biodegradable particles for protein delivery. J Control Release 2002;78:15-24.

60. Davis SS. Nasal vaccines. Adv Drug Deliv Rev 2001;51:21-42.
61. Madan M, Lewis MB, Udupa S, Baig N. In situ forming polymeric drug delivery system. Indian J P S 2009:71;242-51.

62. Sworn G, Sanderson GR, Gibson W. Gellan gum fluid gel. Food Hydrocoll 1995;9:265-71.

63. Doi K. U.S Patent No. 6. 368-616. Washington, DC: US Patent and Trademark Office; 2002.

64. Ando T, Maitani Y, Yamamoto T, Takayama K, Nagai T. Nasal insulin delivery in rabbits using soyabean derivatives sterylglycoside and sterol mixturea are novel enhancers in suspension dosage forms. Biol Pharm Bull 1996;21:862-65.

65. Aikawa K, Matsumoto K, Uda H, Tanaka S, Shimamura H, Aramaki Y, et al. Prolonged release of drug from $\mathrm{O} / \mathrm{w}$ emulsion and residence in rat nasal cavity. Pharm Dev Technol 1998;3:461-9.

66. Tamilvanan S. O/W Nanosized Emulsion, Medical Application Polymer Science Encyclopedia. New York: John Wiley Sons Inc.; 2008.

67. Kararli TT, Needham TE, Griffin M, Schoenhard G, Ferro LJ, Alcorn L, et al. Oral delivery of a renin inhibitor compound using emulsion formulations. Pharm Res 1992;9:888-93.

68. Kararli TT, Needham TE, Schoenhard G, Baron DA, Schmidt RE, Katz B, et al. Enhancement of nasal delivery of a renin inhibitor in the rat using emulsion formulations. Pharm Res 1992;9:1024-8.

69. Li L, Nandi I, Kim KH. Development of an ethyl laurate-based microemulsion for rapid-onset intranasal delivery of diazepam. Int $\mathrm{J}$ Pharm 2002;237:77-85.

70. Zhang X, Wu B. Sub micron lipid emulsion; a versatile platform for drug delivery. Curr Drug Metab 2015;16:211-20.

71. Shinde RL, Bharkad GP, Devarajan PV. Intranasal microemulsion for targeted nose to brain delivery in neurocysticercosis: Role of docosahexaenoic acid. Eur J Pharm Biopharm 2015;96:363-79.

72. Yadav S, Gattacceca F, Panicucci R, Amiji MM. Comparative biodistribution and pharmacokinetic analysis of cyclosporine-a in the brain upon intranasal or intravenous administration in an oil-in-water nanoemulsion formulation. Mol Pharm 2015;12:1523-33.

73. Takenaga M, Serizawa Y, Azechi Y, Ochiai A, Kosaka Y, Igarashi R, et al. Microparticle resins as a potential nasal drug delivery system for insulin. J Control Release 1998;52:81-7.

74. Ishikawa E, Yanaka K, Sugimoto K, Ayuzawa S, Nose T. Reversible dementia in patients with chronic subdural hematomas. J Neurosurg 2002;96:680-3.

75. Illum L, Farraj NF, Davis SS. Chitosan as a novel nasal delivery system for peptide drugs. Pharm Res 1994;11:1186-9.

76. Ugwoke MI, Agu RU, Vanbilloen H, Baetens J, Augustijns P, Verbeke N, et al. Scintigraphic evaluation in rabbits of nasal drug delivery systems based on carbopol $971 \mathrm{p}((\mathrm{R}))$ and carboxymethylcellulose. J Control Release 2000;68:207-14.

77. Callens C, Remon JP. Evaluation of starch-maltodextrin-carbopol 974 $\mathrm{P}$ mixtures for the nasal delivery of insulin in rabbits. J Control Release 2000;66:215-20.

78. Oechslein CR, Fricker G, Kissel T. Nasal delivery of octerotide; absorption enhancement by particulate carrier system. Int J Pharm 1996;138:25-32.

79. Nagai K, Thogersen HC, Generation of beta-globin by sequence specific disteolysis of a hybrid protein produced in E.coli nature 1984;308:810-2.

80. Ikechukwu Ugwoke M, Sam E, Van Den Mooter G, Verbeke N, Kinget R. Nasal mucoadhesive delivery systems of the anti-parkinsonian drug, apomorphine: Influence of drug-loading on in vitro and in vivo release in rabbits. Int J Pharm 1999;181:125-38.

81. Callens C, Pringels E, Remon JP. Influence of multiple nasal administrations of bioadhesive powders on the insulin bioavailability. Int J Pharm 2003;250:415-22. 